Castex), the director (Prof. Dr. Antonio Eqües), the secretary (Dr. R. Castro O'Connor), an assistant secretary, three ordinary members, and two representatives of the British Hospital in Buenos Aires. The Centre's library contains a selection of the most important British medical journals and up-to-date text-books. When an inquiry cannot be answered on the spot, the Centre obtains, through the British Council, information, articles and books (or photostat copies) from Britain. Among the activities are distribution of the "British Medical Bulletin" (Spanish edition), supply of medical films, translations from English into Spanish and Spanish into English, and certain facilities for members wishing to subscribe to British medical journals, or buy British medical books. The facilities are available to medical men in the interior of Argentina, who, since they are not in a position to borrow original books and articles, are supplied with photostat copies.

\section{University of London Appointments}

THE following appointments have been made in the University of London: Dr. D. H. Hey, since $194 \mathrm{I}$ director of research at the British Schering Research Institute, to the University chair of chemistry tenable at the Imperial College of Science and Technology; Dr. F. C. Benham, to the University chair of commerce tenable at the London School of Economies; since 1931 he has been Sir Ernest Cassel reader in commerce at the School. Mr. D. W. Harding, special lecturer in psychology in the University of Manchester, to the University chair of psychology tenable at Bedford. College.

Mr. Raymond Irwin, county librarian of Lancashire, has been appointed to the directorship of the School of Librarianship at University College as from October 1 .

The title of reader in bacteriology in the University has been conferred on Mr. J. C. Cruickshank, in respect of the post now held by him at the London School of Hygiene and Tropical Medicine.

The degree of D.Sc. as an internal student has been conferred on the following: Mr. C. R. Bailey (University College); Mr. R. V. Harris (Imperial College of Science and Technology); Mr. G. W. Padwick (Imperial College of Science and Technology); Mr. L. Young (University College and Imperial College of Science and Technology).

\section{The Night Sky in August}

NEw moon occurs on August 8d. 00h. 32m. U.T., and full moon on August 23h. 12h. 03m. The following conjunctions with the moon take place: August 2d. 23h., Mars $2^{\circ}$ N. ; August 4d. 16h., Venus $1^{\circ}$ S. ; August 5d. 23h., Saturn $1^{\circ}$ S. ; August 9d. 07h., Mercury $9^{\circ}$ N. ; August 11d. 06h., Jupiter $4^{\circ}$ S.; August 31d. 13h., Mars $0.9^{\circ}$ N. In addition to the conjunctions with the moon, Venus is in conjunction with Saturn on August 22d. 04h., Venus being $0.7^{\circ} \mathrm{S}$. Only one occultation of stars brighter than magnitude 6 takes place in August; $\xi$ Tauri is occulted on August 4d. 3h. $28.9 \mathrm{~m}$. Mercury sets at $20 \mathrm{~h} .18 \mathrm{~m}$. at the beginning of the month-half an hour after sunset-and is not well placed for observation. The planet is stationary on August 5 and 29 and is in inferior conjunction on August 20. Venus is conspicuous in the eastern sky, rising at 1h. 1lm., Ih. $22 \mathrm{~m}$. and $1 \mathrm{~h} .50 \mathrm{~m}$. at the beginning, middle and end of the month respectively. Mars, in the con- stellation of Taurus, rises at $23 \mathrm{~h} .47 \mathrm{~m} ., 23 \mathrm{~h}$. $20 \mathrm{~m}$,. and $22 \mathrm{~h} .54 \mathrm{~m}$., at the beginning, middle and end of the month respectively. Jupiter sets about $1_{2}^{1}$ hours after the sun at the beginning of August and less than three-quarters of an hour after the sun at the end of the month, and is not well placed for observation. Saturn can be seen in the early morning hours, rising at $2 \mathrm{~h} .37 \mathrm{~m}$. and $\mathrm{ch} .56 \mathrm{~m}$. at the beginning and end of the month. The Perseid meteors reach their maximum about August 10-12 ; the radiant is at R.A. 3h., dec. $45^{\circ} \mathrm{N}$., close to $x$ Persei.

\section{Announcements}

Prof. H. M. Turnbull, director of the Pathological Institute of the London Hospital and professor of morbid anatomy in the University of London, has been given the honorary degree of D.Sc. of the University of Oxford.

PRoF. A. C. Hardy, regius professor of natural history in the University of Aberdeen and honorary director of oceanographical investigations in the University College of Hull, has been appointed Linacre professor of zoology and comparative anatomy in the University of Oxford, in succession to Prof. E. S. Goodrich.

Dr. Irene Manton, lecturer in botany in the University of Manchester, has been appointed professor of botany in the University of Leeds, in succession to the late Prof. J. H. Priestley.

Mr. A. B. HoRNBLOWER, honorary general secretary of the London Natural History Society, has resigned the position he has held for the past sixteen years, owing to ill-health. Mr. H. A. Toombs of the Geological Department, British Museum (Natural History), Cromwell Road, S.W.7, has been appointed to take his place ; particulars of the Society's activities can be obtained from him.

The Minister of Town and Country Planning, Mr. W. S. Morrison, has appointed the following National Parks Committee: Sir Arthur Hobhouse (chairman), Lieut.-Colonel E. N. Buxton, Mr. John Dower, Mr. Leonard K. Elmhirst, Mr. R. B. Graham, Dr. Julian Huxley, Mrs. Lindsey Huxley and Mr. Clough Williams-Ellis.

THE following have been elected officers of the Institution of Electrical Engineers for the year beginning on September 30: President: Dr. P. Dunsheath; Honorary Treasurer: Mr. E. S. Byng; New Members of Council: Mr. L. H. A. Carr, Mr. J. G. Craven, Mr. J. Eccles, Mr. H. Faulkner, and Prof. Willis Jackson (members); Dr. J. M. Meek (associate member); Mr. A. F. Plummer (associate).

THE report of the proceedings of the nineteenth conference of the Association of Special Libraries and Information Bureaux, December 9 and 10, 1944, has now been published by the Association, price $6 s$. The report includes the papers presented at the Conference together with summaries of the discussions, the presidential address of Sir Frederic Kenyon, a report of the year's work of the Association, 1943-44, reports on the work of the British Council and on the Inter-allied Book Centre evolved by the Conference of Allied Ministers of Education, with brief notes on the British Union Catalogue of Periodicals and on the National Central Library. 